\title{
Selvmordsforebygging i psykisk helsevern - på tide å tenke nytt?
}

\author{
I den senere tid har flere pekt på problemer knyttet til dagens anbefalte risikofaktorbaserte tilnærming \\ til vurdering av selvmordsrisiko og forebygging av selvmord i psykisk helsevern. Her skisserer vi en alternativ \\ tilnærming som kan være mer adekvat i møte med suicidale pasienter.
}

\begin{abstract}
Vi har tidligere pekt på at Nasjonale retningslinjer for forebygging av selvmord i psykisk helsevern (1) kan ha utilsiktede og uheldige konsekvenser for klinisk praksis (2). Mehlum og medarbeidere (3) og Emblemsvåg (4) forsvarer imidlertid retningslinjene ved å sammenlikne selvmordsforebygging i psykisk helsevern med sikkerhetstiltak i veitrafikken.

Det forsterker vår bekymring for at muligheten til å se det enkelte individ drukner i den standardiserte risikofaktorbaserte vurdering som vektlegges i retningslinjene. Straume ser ut til å dele vår bekymring når han med utgangspunkt i retningslinjenes klare anbefalinger om å vektlegge risikofaktorer i vurdering av selvmordsrisiko spør: «Hva ville den selvmordsforebyggende effekten av alternativ tidsbruk vært?» (5).
\end{abstract}

\section{Hva er alternativet?}

Risikofaktortenkningen har sitt utgangspunkt i den biomedisinske sykdomsmodellen. Selv om årsaksbegrepet i seg selv ikke alltid brukes eksplisitt, er det en lineær årsak-virkning-tenkning som ligger bak, der selvmordsatferd blir sett på som et resultat av (forårsaket av) forskjellige risikofaktorer $(6,7)$. Fra et vitenskapsteoretisk ståsted er det imidlertid vanskelig å snakke om årsaksforklaringer til menneskelig atferd (8).

Et alternativ er å legge vekt på intensjonale/teleologiske forklaringer. Sentrale spørsmål i vurderingen av selvmordsrisiko og oppfølging av denne blir da: Hva er det som kommuniseres ved suicidale tanker eller handlinger? Hva er det personen ønsker å oppnå med en suicidal handling? Hvilke problemer er det som skal løses på denne måten (9)? Dermed tar man også inn det kommunikative aspektet som ligger i suicidalitet (9-11). Slike spørsmål vil bidra til å avdekke hvilke(n) subjektiv(e) mening(er) suicidaliteten/selvmordshandlingen har for den enkelte.

Med dette knyttes suicidaliteten til den konteksten den forekommer i. Ut fra et kommunikasjonsteoretisk perspektiv ses suicidaliteten dermed ikke som noe som (bare) ligger $i$ et menneske, men mellom mennesker - det vil si den ses i et relasjonelt og kontekstuelt perspektiv (11). Dette innbefatter også forholdet mellom klient/pasient og behandler. Jobes sier for eksempel at når suicidale personer søker hjelp hos behandler, søker de en relasjon som skal hjelpe dem tilbake til det å ville leve (12).

Tilhørighet og samhandling i en gitt kontekst er en avgjørende forståelsesbakgrunn for å forstå hvilken mening suicidaliteten har for den enkelte, noe som igjen er viktig for å kunne utvikle og tilby adekvat hjelp (9). I klinisk praksis kan dermed det å forstå suicidalitet som kommunikasjon bidra til å hjelpe behandleren til å fokusere behandlingen ved systematisk å kartlegge hvilke aspekter som skal styrkes, utvikles eller endres i personens samspill med sine spesifikke omgivelser. Dette er beskrevet i flere modeller $(10,11)$ og kan for eksempel dreie seg om å arbeide med bedring av pasientens selvoppfatning, arbeide for å få til en endring av omgivelsene eller øve opp mer hensiktsmessige kommunikasjonsferdigheter.

\section{Konklusjon}

Det er mulig at et kommunikativt perspektiv på suicidalitet brukes i klinisk sammenheng noen steder. Det er imidlertid helt fraværende i de nasjonale retningslinjene (10). Dette til tross for at to av nestorene i amerikansk suicidologi, Farberow \& Shneidman, allerede for over 50 år siden beskrev selvmordsatferd som kommunikasjonshandlinger (13). Åtte år for de nasjonale retningslinjene ble publisert pekte dessuten Bøe \& Thomassen på uheldige konsekvenser av standardiserte prosedyrer i psykiatriske institusjoner når det gjaldt for eksempel suicidalitet (14). De fant at slike prosedyrer sto i veien for individuelle vurderinger og fagfolkenes mulighet til å utnytte sin kompetanse.

Et kommunikativt perspektiv på suicidalitet åpner for nettopp dette. Når det nå fra flere hold pekes på problemer med standardiseringen og den sterke vektleggingen av risikofaktorer i selvmordsrisikovurderinger og forebygging av selvmord i psykisk helsevern, er det kanskje verdt et forsøk å skifte perspektiv?

\section{Heidi Hjelmeland}

heidi.hjelmeland@svt.ntnu.no

Julia Hagen

Birthe Loa Knizek

Heidi Hjelmeland (f. 1960) er professor i helsevitenskap ved Institutt for sosialt arbeid og helsevitenskap, Norges teknisk-naturvitenskapelige universitet, og rådgiver ved Ressurssen- ter om vold, traumatisk stress og selvmordsforebygging, Region Midt-Norge.

Forfatter har fylt ut ICMJE-skjemaet og oppgir ingen interessekonflikter.

Julia Hagen (f. 1975) er stipendiat ved Avdeling for sykepleierutdanning, Høgskolen i Sør-Trøndelag, og ph.d.-kandidat i helsevitenskap ved Institutt for sosialt arbeid og helsevitenskap, Norges teknisk-naturvitenskapelige universitet. Forfatter har fylt ut ICMJE-skjemaet og oppgir ingen interessekonflikter.

Birthe Loa Knizek (f. 1957) er klinisk psykolog og professor ved Avdeling for sykepleierutdanning, Høgskolen i Sør-Trøndelag.

Forfatter har fylt ut ICMJE-skjemaet og oppgir ingen interessekonflikter.

\section{Litteratur}

1. Nasjonale retningslinjer for forebygging av selvmord i psykisk helsevern. Oslo: Sosial- og helsedirektoratet, 2008.

2. Hagen J, Hjelmeland H, Knizek BL. Overdreven tro på selvmordsrisikovurderinger? Tidsskr Nor Legeforen 2014: 134: 394.

3. Mehlum L, Ness E, Walby FA. Re: Overdreven tro på selvmordsrisikovurderinger? Tidsskr Nor Legeforen 2014; 134: 593.

4. Emblemsvåg ER. Re: Overdreven tro på selvmordsrisikovurdering? Tidsskr Nor Legeforen 2014; 134: 593

5. Straume S. Selvmordsforebyggingens pris. Tidsskrift for Norsk psykologforening 2014; 51: 246-7.

6. Boldt M. The meaning of suicide: implications for research. Crisis 1988; 9: 93-108.

7. Hjelmeland $\mathrm{H}$, Knizek BL. Why we need qualitative research in suicidology. Suicide Life Threat Behav 2010; 40: 74-80.

8. Gilje N, Grimen H. Samfunnsvitenskapenes forutsetninger. Oslo: Universitetsforlaget, 1993

9. Hjelmeland H, Knizek BL. Hva er meningen? Selvmordsatferd som kommunikasjon. Sosiologi i dag 2013; 43: 7-30.

10. Knizek BL, Hjelmeland $\mathrm{H}$. A theoretical model for interpreting suicidal behaviour as communication. Theory Psychol 2007; 17: 697-720.

11. Fleischer E. Den talende tavshed. Selvmord og selvmordsfors $\varnothing \mathrm{g}$ som talehandling. Odense: Odense Universitetsforlag, 2000.

12. Jobes DA. Collaborating to prevent suicide: a clinical-research perspective. Suicide Life Threat Behav 2000; 30: 8-17.

13. Farberow NL, Shneidman ES. red. The cry for help. New York: McGraw-Hill, 1961/1965.

14. Bøe TD, Thomassen A. Mot en mer menneskelig psykiatri. Fra autoritet til dialog og deltakelse. Oslo: Universitetsforlaget, 2000.

Mottatt 1.4. 2014, første revisjon innsendt 23.4. 2014, godkjent 23.5. 2014. Redaktør: Kari Tveito.

Publisert først på nett. 